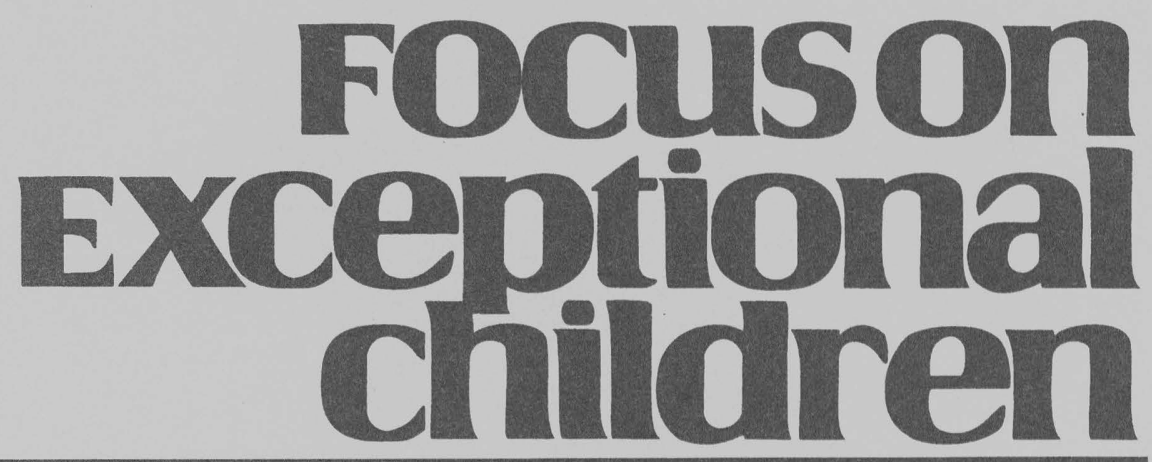

\title{
Strategies for Teaching Social Studies
}

\author{
Kathleen McCoy
}

Picture this: Elizabeth, a seventh-grader complete with technicolor nails and braces on her teeth, twirls her hair and tries to look attentive. Her teacher, Mr. Bogel, is waxing poetic about the marvels of the West Indies. In theory, Elizabeth is taking careful notes, recording Mr. Bogel's lecture. In practice, Elizabeth is compiling a list of cosmetic products that are prerequisites for the spring dance. Somewhere on the edge of her consciousness Elizabeth hears, “...chapter 13 on next Tuesday's quiz." Elizabeth is fully aware that receiving poor grades in social studies results in mall restrictions. Somewhat reluctantly, Elizabeth leaves the world of makeup and trods page by page through the chapter to discover the wonders of Central America as defined by the Chapter Review on page 120. To find the answers to the chapter questions, Elizabeth reads line by painful line. Too bad that she doesn't know how to use section headings to locate information - an activity that takes most kids 30 minutes takes a whopping 4 hours for Elizabeth. No wonder she hates social studies.

In the next room, Jorge has just finished placing the final sugar cube on top of the Great Pyramid. Last week he mummified a cornish game hen, and next week he is going to finish writing a play about ancient Egypt. His part is that of a pharaoh called Ramses who meets aliens from outer space. Jorge is not quite sure who Ramses is or even if Egypt exists, but he is thrilled that his mother made him a costume decorated with gold and jewels. Jorge also is happy because his teacher, Ms. Goodwind, likes arts and crafts projects and doesn't like textbooks or tests. No written records of Jorge's progress in social studies will ever be unearthed.

\section{STUDENT DIVERSITY}

How common are these two scenarios in today's social studies classes? In an area of study where diversity is respected, how disparate can instructional methods be to honor the Expectations of Excellence, curriculum standards set by the National Council for the Social Studies Task Force (NCSS, 1994)? How disparate can instructional methods be to meet the diverse needs of today's students? As a result of inclusion, more than $70 \%$ of

Kathleen McCoy is an associate professor in the Department of Special Education in the College of Education at Arizona State University. This article was adapted from a chapter in Educating Students With Mild Disabilities: Strategies and Methods ( 2 nd ed.), edited by Edward L. Meyen, Glenn A. Vergason, and Richard J. Whelan and published by Love Publishing Company. 
students with learning disabilities (LD), mild mental handicaps (MH), and behavior disorders (BD) are being educated in the general education setting (Ysseldyke \& Algozzine, 1990). In addition, many students with mild disabilities who also are limited in using English as their primary language of instruction are included in general education settings (Gersten, Brengelman, \& Jimenez, 1994). Given the diversity represented by children with mild disabilities, the 10 themes that form the framework of the social studies standards (NCSS, 1994) almost seem to have been designed specifically for them (pp. X-xii):
1. Culture
2. Time, Continuity, and Change
3. People, Places, and Environments
4. Individual Development and Identity
5. Individuals, Groups, and Institutions
6. Power, Authority, and Governance
7. Production, Distribution, and Consumption
8. Science, Technology, and Society
9. Global Connections
10. Civic Ideals and Practices

\section{Focuson
Exceptional children}

ISSN 0015-511X FOCUS ON EXCEPTIONAL CHILDREN (USPS 203-360) is published monthly except June, July, and August as a service to teachers, special educators, curriculum specialists, administrators, and those concerned with the special education of exceptional children. This publication is annotated and indexed by the ERIC Clearinghouse on Handicapped and Gifted Children for publication in the monthly Current Index to Journals in Education (CIJE) and the quarterly index, Exceptional Children Education Resources (ECER). The full text of Focus on Exceptional Children is also available in the electronic versions of the Education Index. It is also available in microfilm from Xerox University Microfilms, Ann Arbor, MI. Subscription rates: individual, $\$ 36$ per year; institutions, \$48 per year. Copyright (C) 2005, Love Publishing Company. All rights reserved. Reproduction in whole or part without written permission is prohibited. Printed in the United States of America. Periodical postage is paid at Denver, Colorado. POSTMASTER: Send address changes to:

Love Publishing Company

Executive and Editorial Office P.O. Box 22353

Denver, Colorado 80222

Telephone (303) 221-7333

\section{The Need for Social Studies}

Students with mild learning problems, such as Elizabeth and Jorge, need to understand how culture accepts or rejects their special needs and who they are relative to others in the room and the world. A knowledge of historical roots related to disabilities in society can help students with mild learning problems connect to others in the class and develop a sense of relatedness. Students need to learn about people, places, and human-environment interactions and discover how their personal identity is shaped by their culture, by groups, and by institutional influences such as schools, churches, families, and government systems. They need to understand how their individual rights can be protected within the context of majority rule and how goods and services can be distributed. They need to learn about their role as citizens and how they can make a positive difference in their class and in their community. In sum, students with special learning problems, like all children, need to learn social studies.

\section{Social Studies Defined}

The area of social studies, as can be seen from the 10 themes from the Expectations for Excellence, is a complex area of study focusing on the integration of social science, behavioral science, and humanities that forms the basis of civic competence in the United States. The Board of Directors of the NCSS (1994), the primary membership organization for social studies educators, has adopted the following definition:

\footnotetext{
Social studies is the integrated study of the social sciences and humanities to promote civic competence. Within the school program, social studies provides coordinated, systematic study drawing upon such disciplines as anthropology, archaeology, economics, geography, history, law, philosophy, political science, psychology, religion, and sociology as well as appropriate content from the humanities, mathematics, and natural sciences. The primary purpose of social studies is to help young people develop the ability to make informed and reasoned decisions for the public good as citizens of a culturally diverse, democratic society in an interdependent world (NCSS, 1994, p. 3).
}

\section{SOCIAL STUDIES INSTRUCTION FOR CHILDREN WITH MILD DISABILITIES}

\section{The Challenge}

The challenge is how to provide access to social studies content in a general education setting to children with mild disabilities. For at least 20 years the traditional textbookbased instructional approach has been found to be ineffective (Goodlad, 1984; Turner, 1976). The traditional method of lecture-read-group discussion is likely to miss the needs of many students with learning problems (Horton, Lovitt, \& 
Slocum, 1988), especially those at the middle and secondary levels, where textbooks are heavily used. Overwhelming numbers of students with learning problems are reading two or more years below grade level - never mind that they lack strategies for comprehension skills such as drawing inferences or locating main ideas to apply to real-world situations (Ellis, 1994). If the model of instruction, traditional or otherwise, does not match the needs of children with mild disabilities, what model for social studies instruction can be used?

\section{Accommodations in General Education Settings}

\section{Use of Instructional Interventions}

Before attempting to implement instructional strategies specific to social studies, we might want to find out what light research findings can shed upon accommodating student needs in general. Results of research conducted to determine the extent to which accommodations for individual differences have occurred have been somewhat dismal.

For example, in a detailed analysis of the first year of a mainstreaming project, Baker and Zigmond (1990) examined the educational practices in general education classes in grades $\mathrm{K}-5$. They were documenting changes necessary to facilitate full-time inclusion for students with learning disabilities. The overall impression was of undifferentiated group instruction-so much for meeting individual needs. Teachers essentially followed district mandates and lesson plan guides. Instruction was directed to the whole class. The teachers acknowledged diversity but provided lessons based on uniformity.

Unfortunately, Baker and Zigmond's observations are supported by the results of many surveys designed to poll teachers about their experiences and attitudes concerning the inclusion of children with special needs in their classes. Questionnaires typically address attitudes toward modifying or identifying strategies that could be used in the general education setting with children with mild disabilities. Results across studies find that, though teachers indicate the value of providing interventions, they generally don't find such provision feasible (Bender \& Ukeje, 1989; Schumm \& Vaughn, 1991; Whinnery, Fuchs, \& Fuchs, 1991).

\section{Acceptable Accommodations in General Education Settings}

According to Schumm and Vaughn (1991), the kinds of adaptations that teachers perceive as most desirable are providing reinforcement and encouragement, establishing a personal relationship with a student with special needs, and involving the student in whole-class activities-the same behaviors that would be expected to be found toward children without special needs. Teachers are least likely to accept strategies that require systematic evaluation of goals or adjustment of materials and instructional practices for learners with special needs. The likelihood of adapting longrange plans, adjusting physical arrangements of the room, or modifying scoring and grading criteria is minimal.

Without some type of intervention, implementation of individualization or accommodation in the general education setting is unlikely. The question now becomes not only what strategies to implement but also how to implement these strategies. Research results suggest strongly that instructional strategies can be utilized to teach content areas such as social studies to children with mild learning problems (Bulgren, Schumaker, \& Deshler, 1994; Carnine, Crawford, Harniss, \& Hollenbeck, 1995) but must be implemented with a minimum of disruption to normal classroom routine. Students with mild learning problems, like all children, need instruction to become better citizens by developing a sound knowledge base in social studies. To receive instruction in social studies in an inclusion setting, students with mild disabilities need personalized modification of materials that is not disruptive or difficult to implement.

\section{Increasing Acceptance of Providing Accommodation}

Acceptance and utilization of strategies for instructional accommodation may be increased by making the students aware of possible strategies, providing experience with the strategy, and increasing opportunities for the students to practice the strategy (Schumm \& Vaughn, 1991). Special education teachers are the ones responsible for providing awareness and in-class experiences with accommodation strategies. As a member of an instructional team, the special educator has the responsibility for modeling strategies, leading other team members through these strategies, and testing how well these strategies work within the context of social studies in the general education setting. To make suggestions or recommendations to the general educator without field-testing in the general education classroom is like asking the CEO of General Motors to mass-produce a solar car without a prototype-a nice concept but, without evidence of financial success, not likely to be marketed. The inclusionary yellow-brick road leads back to Kansas or, in this case, the special education teacher.

\section{Social Studies Knowledge Base: Preparation of Teachers}

\section{Roles}

The role of the special education teacher is to be the instructional strategist, not the content specialist. The content specialist, usually the general education teacher, theoretically is grounded with a sound knowledge base in social studies. More than likely at grades kindergarten through 
fifth or sixth grade, however, the special educator and the elementary education teacher have about the same amount of background knowledge-a methods course in teaching elementary-age students social studies and whatever general studies courses their university or college requires for graduation. Teachers with a degree in elementary education are prepared in programs heavily weighted in educational methods, usually at the expense of depth of understanding of the course content to be taught (National Commission on Excellence in Education, 1983); the social studies background of most special education majors is not much different from elementary education majors.

\section{Self-Contained General Education Classrooms}

When general educators and special educators have comparable backgrounds, either or both can assume the planning, delivering, and evaluating of instruction. With a common knowledge base, modifications to content are one step closer to reality. Planning is simplified because the step of teaching each other the social studies content can be bypassed. Given most teachers' lack of expertise in social studies at the elementary level, the district curriculum guide, topic coverage in texts, or unit topics designed by expert teachers probably should be used as guides for planning activities. A review of such guides can be completed outside of joint planning time. Because the special education teacher has the same level of expertise as the classroom instructor, joint preparation time for accommodations can be focused on the when and the how but not the what. To the extent that each teacher or group of teachers is flexible and communicates student and classroom needs, accommodations are possible.

\section{Departmentalized Instruction}

When social studies is departmentalized, the content specialist is more likely to have a fairly extensive background in social studies, whereas the special educator's knowledge base in social studies is minimal (Bulgren \& Lenz, 1996). The content specialist must assume responsibility for developing social studies competence in students. This social studies specialist will have to identify critical content for the support teacher who then will have to find ways to teach students remedial or compensatory strategies using that key content in the social studies area.

\section{Identification of Content}

\section{Textbook-Driven Instruction}

When social studies is departmentalized or taught as a separate subject, a text-driven approach supported by teacher-made activities is still the most common format (Bracey, 1993). In addition, many elementary and secondary social studies teachers believe overwhelmingly that the social studies emphasis for students with mild disabilities should be the same as for all students in the class (Passe \& Beattie, 1994). This is not an unreasonable thought considering that when students with special needs grow up, they will be expected to participate as citizens with the same responsibilities as other adults.

Critical knowledge is identified more easily for nonspecialists in settings that use a social studies text as a basis for instruction. The content is in the book and usually has been developed by experts in social studies. If Mr. Atwood wants to teach a unit on critical thinking, for example, all he has to do is turn to a chapter 6 section, "Whose View of the World? Maps and Their Uses," in the text. Chapter 6 has been thoughtfully labeled "Critical Thinking Activities." Though it is difficult to determine if the chapter content is driving Mr. Atwood or Mr. Atwood is driving the chapter content, the essential ideas are clearly presented in the chapter outline detailing the anecdotes, real-life situations, and references.

Because Mr. Atwood is following the chapter outline, Mrs. Carpenter, the special education teacher, is able to design modified materials for the students in Mr. Atwood's social studies class. Instead of spending a lot of planning time trying to identify content, she can spend her time modifying content to meet student needs. Because the whole idea of inclusion is to educate children with special needs in the general education setting, Mrs. Carpenter can develop small-group or whole-class activities that reinforce the content presented in chapter 6 without becoming a social studies specialist. This is a good idea because Mrs. Carpenter is not a social studies expert, nor is she likely to become one.

Mrs. Carpenter can complement Mr. Atwood's lesson on reading map symbols by providing material that moves the children gradually from pictorial and semipictorial symbols on maps. These first maps may be made by the children and, in addition to drawing, cutting, and pasting, Mrs. Carpenter can provide cues, prompts, or models for the children who need them. Matthew, for example, may benefit from having models of pictorial representations attached to his drawing paper. The models representing real-life encounters, such as a bike crossing or no-smoking sign, can be a first step in helping Matthew understand symbols before he moves to more abstract legends.

Mrs. Carpenter next shapes instruction to lead to the more abstract symbols used on conventional wall maps, globes, and maps that are included in the textbook. She either can take materials developed by Mr. Atwood and adapt them or she can provide adapted material for Mr. Atwood to be used with children like Matthew and Sammy. Mr. Atwood and Mrs. Carpenter both know which children need modification, but Mrs. Carpenter's role is to go beyond 
the norm, because she is the teacher of children with special education needs, and include modified materials embedding basic skill instruction. No one said inclusion was easy, but having a text as a guide can be extremely efficient.

\section{Value of Textbooks}

Even though the traditional method of lecture-read-group discussion may not be effective (Horton, Lovitt, \& Slocum, 1988), textbooks need not be abandoned. In fact, for teachers trained in elementary education, logic dictates use of a social studies text in some way. The text may be used as a primary resource, as a supplemental text, or as a reference manual. How the text is used depends on the delivery system in the classroom and the extent to which the teacher is responsible for the curriculum in the text. For some teachers, especially those whose primary education has been in special education or elementary education, and for some students who need structure, the text provides an excellent organizational and content resource.

\section{Social Studies Content Across Curricula}

When social studies is presented as part of a basic core, crossover or integration with other core content, such as literature or science, is to be expected. Key content can be more difficult to determine in the social studies areas when it is infused with other content. In an integrated approach, social studies is viewed as a composite subject. The various elements of social studies are history, geography, economics, political science, anthropology, sociology, and psychology. Morals and ethics are included from philosophy, and elements from the humanities and fine arts such as literature, art, and art history also are part of this composite. Because social studies is a blend of many disciplines, the focus of social studies becomes human behavior-how people interact with the environment and with the innumerable ways in which people live in society (Welton \& Mallan, 1996).

In this model of social studies, content cuts across disciplines. The area of humanities, for example, is often integrated with social studies as a means of understanding cultural aspects of people or periods of time (Smith, Monson, \& Dobson, 1992). In the study of westward expansion in the United States, for example, the book Long Ago in Oregon (Lewis, 1987) can be used to reveal the daily lives of people in a town in Oregon during the early 19th century. The poetic vignettes in the book can be integrated with more literal concepts presented through history texts or guides. The content emphasis in an interdisciplinary approach varies with the interests, needs, and knowledge base of the instructor or instructors. The integrated approach to social studies instruction is delivered most often in elementary schools and in junior high settings that use a thematic core approach.

\section{Whole-Language and Integrated Curriculum}

Integrated instruction often is paired with a whole-language orientation. Choosing and elaborating on a theme in social studies through literature, reading, and writing represents the heart of whole language (James \& Zarrillo, 1989). To a greater or lesser extent, whole-language integration with social studies translates to minimal or no use whatsoever of textbooks. These instructors believe students will develop and sustain interest in social studies by engaging in democratic processes such as collaboration, discussions, cooperative learning, problem resolution, and so on. Overuse of the text prevents active engagement in these democratic processes. Whether use of a textbook leads or does not lead to active participation is not the issue; the point is that many classes using an integrated approach do not use textbooks as a major source of content.

Teacher planning in an integrated model first must identify which social studies concepts should be introduced to students. Planning time, as all teachers know, is a precious commodity, most often absorbed in conferences, grading, and administrative tasks (Bulgren \& Lenz, 1996). Insufficient planning time makes the integrated/whole-language model difficult to implement for students with special needs.

Next, the type of learning experiences have to be outlined in social studies as well as other content areas. Skills accompanying the lesson also must be identified. The learning climate must encourage both inquiry and choice. Suggested informal guidelines for planning an integrated social studies and whole-language unit (Routman, 1994) are as follows:

1. Develop a semantic web as the class or group brainstorms the topic.

2. Have students select a subtopic by listing their first, second, and third choices of subtopics.

3. Divide the students into small groups of up to four students per subtopic.

4. Have the groups develop questions to research for their subtopic of study.

5. Have each group meet with another group to confer over the questions each group generated for the respective subtopics.

6. Have each group establish a format for using resources to discover the answers to the questions members generated about the subtopic.

7. Have all of the students take notes on their subtopics.

8. Ask students to use their notes to write rough drafts.

9. Have each group present the information its members gathered to the entire class. (A variety of formats may be used: quiz shows, radio shows, festivals, plays, travelogues, etc.)

10. Have classmates make oral presentations. After each one, students must give at least two positive statements 
before a student can make positive suggestions for improvement.

11. Evaluate group interactions and content learned. This is done by the teacher and through student self-evaluations. In addition, an essay test given by the teacher may be included at this point.

As can be seen from a brief analysis of these guidelines, the special education teacher has quite a challenge. Not only must the content be identified, but strategies for teaching children with mild disabilities also must include instruction in social skills (recommendations $1-5,10$, and 11), writing strategies (recommendations 5, 6, 8), notetaking strategies (recommendations $4,7,8)$, and public speaking strategies $(9,10,11)$. For students who have mild learning problems, almost all these areas require instructional guidance and almost all of these strategies will be needed within 2 to 3 weeks.

The good news is that once the special education teacher has developed instructional techniques for delivering these strategies, the approaches can be used repeatedly for whatever topics follow. The bad news is that development of these strategies in a whole-language setting is teacher-intensive and not that many teachers are available (McCoy, 1996). Often, instruction is left to peers who may or may not have the skills themselves. Learning under these guidelines is indeed a social activity.

\section{MODELS OF SOCIAL STUDIES INSTRUCTION}

\section{Respecting the Model}

The challenge facing the special education teacher is twofold:

1. The student's needs must be respected and accommodated.

2. The social studies teacher's needs must be respected and accommodated.

No matter how the special education teacher feels about traditional instruction or arts and crafts as an instructional approach to social studies, if the method is being used in the classroom, accommodations must account for the approach as well as the student's instructional needs.

Ignoring diversity or, at the other extreme, being paralyzed by differences found in students and instructional approaches is dysfunctional. For example, Ms. McMillan, a special education teacher and recently converted true believer of whole-language philosophy, is horrified to team with Mr. "King of the Textbooks" Parker. She thinks no real learning can come from a classroom that uses basal social studies texts and requires that children learn facts through the dreaded "m word" (memorization, for those of you too young to remember!). Mr. Parker is so repelled by Ms. McMillan that he shuts her out, literally and figuratively, from the class. Too bad for $\mathrm{Al}$, Stan, and Rob, whose IEP goal of receiving equal access to social studies content in the general education setting is highly improbable. The challenge is to find a flexible path between the McMillans and the Parkers-instruction that accounts for student need more than for instructor bias.

\section{Basic Social Studies Models}

Three models used frequently in social studies instruction are (a) textbook-based plans, (b) theme- or topic-oriented plans, and (c) child-centered plans. At the heart of each of these models is the application of democratic beliefs and values (Saxe, 1994). Each of the three basic models may have one or many types of focus (e.g., awareness of self in a social setting and/or sharing earth space with others). For example, if the central focus in first grade is the individual in primary social groups, the democratic freedoms and responsibilities addressed are impartiality, freedom of worship, and consideration for others. These opportunities can be illustrated when an altercation is reported (the teacher can try to find out exactly what happened before taking action), by stressing that each family decides whether or not (and how) to worship, and in the lesson that everyone has a right to a turn.

Textbook-based plans are developed by teachers who use the textbook or other curriculum guides to determine the nature and content of the program. Theme- or topic-oriented plans are similar to textbook plans, but they rely less on the text. More of the teacher's and students' influence is found in topic-oriented planning. Students, for example, are more involved in focus activities and questions. Of the three models, child-centered plans are the least structured. Children help decide the study units with the teacher. Jointly, they plan how they will work, activities to do, and how to share ideas with class members.

\section{Characteristics of Models}

Each model has strengths and limitations. Consequently, many social studies instructors combine or use elements of all three approaches, depending upon instructional content and class makeup. Text-based or text-driven instruction is more common at upper elementary and secondary levels; theme instruction often is integrated with content from other subject areas, such as literature, and typically is found in middle schools and junior high schools that use a team approach. Child-centered plans are associated most often with lower elementary grades and with teachers who hold a whole-language philosophy. In a text-driven approach, students will need to learn from lectures and textbooks. In a more child-centered approach, students will need to learn from each other as well as printed material. Depending on a teacher's philosophy and background, blends of both 
approaches in social studies instruction can be found at any level in any model and accommodations can be made within and across models.

\section{Commonalities in Models}

Most approaches to social studies instruction attempt to teach students how to think critically when evaluating information, how to problem solve, how to hypothesize, and how to infer information about how people act and react to their world. Projects that reflect students' reasoning abilities often require utilization of reading, writing, and organizational skills.

Reading Material. In text-driven approaches, students are expected to read texts, answer study questions, often taken from the book, and complete reports on some aspect of study (e.g., "Our Home and Families" or "Native American Beliefs About the Earth"). In lieu of textbooks or to complement textbooks, the more child-centered or topic-oriented approach relies heavily on tradebooks chosen by teachers to represent the theme of study (e.g., The Josefina Story Quilt by Coerr, 1986; Loving the Earth: A Sacred Landscape Book for Children by Lehrman, 1990).

The ultimate goal of reading in social studies areas is to comprehend and apply social studies content to life issues. The guiding principles for engaging in reading activities apply equally to textbooks, tradebooks, magazines, newspapers, or any other form of printed material. Teachers guide reading by first activating prior knowledge and setting the purpose for reading. Strategies for reading the material are set by reviewing the title and subheadings, looking at pictures, asking questions about the content before reading, or inspecting questions that may accompany the text.

As students read content, teachers monitor comprehension by asking questions and clarifying concepts. Contextual analysis is used to understand new terms and integrate new information. After reading has been completed, teachers provide opportunities for students to think about what was read and summarize major concepts and details. Teachers guide students to sources that could provide additional information about aspects of the material that are particularly interesting or confusing.

The role of the special education teacher is to ensure that students with mild learning problems are exposed sufficiently to principles of reading to meet their needs. The basis for reading instruction shifts to the required reading material in the class, whether tradebook or textbook. The extent to which the special education teacher must augment instruction is in direct relationship to the extent to which the social studies teacher applies principles of good reading instruction to the material used to teach social studies concepts.
Projects. Projects, whether formal reports or student-created dramas or dioramas, require organizational skills to complete. Checksheets are simple yet powerful guides that can assist students with mild learning problems in organizing projects. Checksheets are simply written task analyses with a means to indicate that the task has been completed. The checksheets for the same task, just as a task analysis for the same task, can be modified according to student skill.

Suppose the class is assigned a project to create a collage representing diversity in their class. For some children a step-by-step procedure can serve as an organizational guideline. Shelley, for example, has great ideas but doesn't know how to focus to get started. Her checksheet might place greater emphasis on the steps needed to get started. For example:

Step 1: Brainstorm what you like best about five of the boys and five of the girls in the class.

Step 2: Combine your brainstormed ideas into five or fewer categories.

Step 3: Find or create a picture or symbol to represent the categorical headings.

Michael, who has problems with task completion, may need more steps indicating what is expected in the final product (e.g., a step directing him to complete at least five pictures or symbols, a step directing him to label each picture with a student's name, a step telling him to glue each labeled picture onto the base sheet, and a final step reminding him to place the finished collage in the teacher's "work completed" basket). For Brianna, who has problems with pace, a checksheet could be modified to indicate task time required for clusters of steps (e.g., 5 minutes for steps $1-3,10$ minutes for steps 4 and 5 , and so forth).

Writing. Often social studies classes, integrated or not, require a heavy emphasis on writing, including spelling, punctuation, and reference skills such as location and documentation. Techniques that have been found successful in teaching these basic skills out of context also can be applied to teaching them in the context of social studies content. When writing a story, for example, key vocabulary terms specific to the content can be listed in a prominent place in the classroom. For students who do not read well, pictures or cues next to terms can help them identify words without excessive teacher contact. The list serves as a reference point and frees children to express their ideas without being limited because of poor spelling skills. Attribute planning forms (Ellis, 1993) - listing all the characteristics of something or someone-or story maps-making a semantic map with one item, such as conservation, in the middle with items webbing out in all directions-have 
been used successfully for a long time. Techniques such as these lend themselves easily to social studies content.

\section{INSTRUCTIONAL FORMATS}

\section{Cooperative Activities}

More often than not, text-based, theme-oriented, and child-centered instruction in social studies borrows heavily from instructional formats for group activity. Activities often range from cooperative groups, in which children work together to complete tasks, to large-group or whole-class formats, in which a lot of independent work is completed.

\section{Structuring Cooperative Group Activities}

Cooperative group work can be structured in many different ways, such as cooperative learning, the jigsaw method, and Student Teams Achievement Division (STAD). The assumption behind cooperative approaches is that teamwork is innately more motivating and instructional than blanket group work. The power of social interactions and cooperation found in cooperative formats are posited to be mini-reflections of society at large-that is, citizens working together in task-oriented groups.

Cooperative Learning. In cooperative learning, children work in small groups to accomplish a common goal. The teacher acts as a facilitator and the students serve as resources to each other. Roles are assigned, and together the group produces a project or completes a task. Often everyone in the group receives the same grade. The basic principle of group composition in cooperative learning is to provide the greatest mix possible given the student population. This mix includes academic abilities, interpersonal skills, gender, ethnicity, disability, language, race, and social class. Small groups reflect the composition of the whole class. Ability grouping is not acceptable because homogeneous grouping minimizes the mix. All the most popular students cannot be in one group; neither can all the less academically able students constitute a group.

Heterogeneous grouping lends itself well to inclusionary instruction. Deciding how to form groups is not without precedent. In general, some social and academic talents that are helpful in assigning children to groups are skills in reading, writing, planning, decision making (comparing alternatives), notetaking, brainstorming, and using reference material such as the Internet. The following six guidelines for forming groups have been suggested by Parker and Jarolimek (1997):

1. Work, not play. The purpose of cooperative grouping is work, not play. When placed in the same group, friends tend to play, so they usually should not be placed together.
2. Random assignment. To result in mixed groups, they can be formed alphabetically or by numbers in birthdays until the teacher learns the characteristics of the students. Adjustments can be made as need arises.

3. Purposeful mixing. As the teacher becomes familiar with students' work habits and interpersonal skills, groups can be mixed purposefully. Mixing students who are strong and weak on each of the characteristics is one way to balance groups. Students with poor interpersonal skills or poor academic histories, however, should not be placed together.

4. Special helper. A variation on purposeful mixing is to select one or more students for each group to act as a special helper. Suppose the teacher has decided that groups of four children are to write historical fiction about Harriet Tubman or James Madison. Each student is to do a different chapter, but the group would be more efficient if someone who likes to sketch is in each group, or someone who is a strong planner (i.e., a member who can help the group decide on four different chapter topics).

5. Index cards. The teacher writes each student's name on an index card, piece of construction paper or tagboard, or popsicle stick or tongue depressor. Based on the type of group work, a special helper is chosen for each group according to the strengths most necessary for that task. Next, the other children are sorted in the greatest mix possible to each of the special helpers. A random technique obtained by shuffling the deck of index cards or picking popsicle sticks also can be used to form groups around the special helper.

6. Duration. Group membership lasts until the cooperative task is completed or until the group has learned how to work cooperatively. Although the group remains the same, the task changes (e.g., from making a paper maché globe to writing a biography of Martin Luther King Jr.). A new task is a chance for the teacher to choose a different set of helpers.

The Jigsaw Method. The jigsaw method is a variation of cooperative learning. In this approach, each group produces some aspect of a project. When all the groups have finished their projects, the jigsaw puzzle is complete. In Mr. Brenes's class, for example, the students have been divided into six heterogeneous groups of six students each. He gives each group or team the same assignment: to produce a short report that shows examples of, and clearly distinguishes among, goods and services in six different areas in Spain: health, food, transportation, recreation, housing, and education. Each team member is responsible for one area. Pedro, for example, must research health, 
Antonia has food, and so forth. To complete the puzzle takes all six collages; each member contributes one part of the puzzle. Before the puzzle is completed, the teams split up into topic areas. Now Pedro, who is from Team A, meets with all the other children on the other five teams who have been assigned the topic of health. This temporary "health team" meets and plans how to find information that represents the topic of health services in Spain. Members of the temporary health team can work together or alone and, once the task is completed, return to the original teams to assemble the whole report representing the six topic areas.

STAD. In the STAD approach to cooperative group work, the students first listen to the teacher present information, then begin cooperative work. Before the teacher lectures or presents, the students are placed in groups. Then the teacher presents the rationale and content of the lesson. Suppose, in a lesson on map legends, Ms. Soroka takes 15 minutes or so to display three different maps, explaining the design and function of the legend on each. Next, she gives the group one handout with questions and another with responses. Only one copy of either the questions or the responses is given to each group so that group members must share materials. Each group is given 20 minutes to accomplish their assignment: to understand why the answers are correct. Finally, the students are given a short quiz over the questions and answers. The group with the highest average score (or that shows the greatest improvement over the last quiz average) is rewarded with special certificates and honorable mention in the class newsletter.

Cooperative Group Model. Cooperative group activities mirror society. The positive effects of group activities on the achievement and self-image of children with mild learning problems are clear. Students assist each other, working together to complete class activities of high caliber. Strengths are emphasized, and differences are minimized. When cooperative learning groups increase the participation of low-status children, their achievement level is raised. Four factors that influence positive academic achievement for children with mild learning problems in cooperative learning groups have been identified in Cohen and Lotan (1990) and Cohen, Lotan, and Catanzarite (1990):

1. Opportunity for multiple roles in the group

2. Learning tasks involving multiple abilities

3. Teacher intervention for low-status children

4. Simultaneous groups and concept emersion

\section{A Model Cooperative Group Lesson}

Using an example designed for teaching fourth-graders responsibility (Fernlund \& Crowell, 1990) demonstrates how the achievement levels and self-esteem of Jenny, Sally, Bridget, and Carmella are influenced as they work cooperatively on this unit. The basis for the unit is the story of the little match girl, a poor child who was sent to sell matches in the cold. In the original story, this sad little girl went to sleep in the snow and died.

Experiences. The teacher, Ms. Martinez, encourages multiple roles by asking the children to participate in three different experiences with the concept of responsibility as related to the story. One experience is a role-playing task in which the four children write a story ending or, if told the ending, make up a new one. Another experience is the creation of decision trees in which the children depict the choices the girl faces and the consequences of each choice. The four girls then dramatize the story's new ending. A third experience requires the children to produce a short narrative in which they must reflect on the match girl's life, followed by small-group discussion guided by the following questions:

\begin{abstract}
In the story of the little match girl, we find her sad, cold, and lonely. Who do you think should have taken responsibility for her? Was it the girl herself, her parents, her relatives, people passing by? Decide for yourself, and write your thoughts before you discuss them with your group.
\end{abstract}

Jenny, Sally, Bridget, and Carmella then discuss their opinions.

Highlighting Abilities. Ms. Martinez designed experiences that immersed Jenny, Sally, Bridget, and Carmella in the concept of responsibility, as well as highlighted their different abilities: acting for Jenny, writing for Sally, discussing and speaking for Bridget, and drawing for Carmella. The tasks are open-ended, and the students are encouraged to rely on their group, rather than their teacher, for direction.

Limited teacher interaction provides recognition and praise for Bridget's discussion talents and Carmella's drawing skills and thus builds their self-esteem. Their teacher provides status intervention for Carmella, who has problems writing, when assigning the decision drawing tree. The decisions are listed, and a happy face or sad face, indicating the worth of the choice, is drawn beside the decision. Bridget, who struggles with reading, is quite skilled at role playing and creating new endings for stories. Ms. Martinez has designed a unit with lessons valuable for building students' participation skills and creating a positive social studies environment (Farris \& Cooper, 1994).

\section{Potential Problems}

The bright side of group cooperative lessons is seen in the model lesson on responsibility. Now for a word from the dark side: At times cooperative group work breaks down because some of the children, often those with mild learning 
or social disabilities, do not do any of the work. Some of the children accomplish little or nothing and by default force others in the group to carry them through the activity. As part of the cooperative group, these children earn high grades, but individually they may have learned nothing related to the social studies content. The danger in cooperative group instruction is that some children's problems are hidden sufficiently by group participation so that the teacher's attention is not directed to their needs.

\section{Whole-Class Activities: Large Group}

\section{Text-Based or Theme-Oriented Plans}

Even before instruction begins, the text-based social studies teacher decides the basic approach to take with the subject. In broad terms, two approaches are used: depth or breadth.

1. In the narrow and deep approach, a lot of time is spent on one particular subject, such as 10 weeks on ancient Egypt, which ensures depth of thought.

2. The alternative is to spend less time on a broader range of subjects (e.g., 2 weeks on ancient Egypt, 2 weeks on ancient India, 2 weeks on ancient China, 2 weeks on ancient Europe, and 2 weeks on ancient Rome). This ensures breadth.

The social studies teacher's reason for choosing one or the other of the approaches depends on the purpose of instruction.

The in-depth approach uses social studies content as a way to develop thinking skills. The topic is not as important as the need to expand students' ability to develop concepts and problem-solving skills. As a result instruction aims at providing an in-depth look at a culture or place by including art, literature, and beliefs and practices, as well as more traditional social studies content, and by limiting exposure to a few topics.

While also valuing higher level outcomes, the second approach reflects a more traditional view that teachers are to provide the background - that is, a broad knowledge basefor the next teachers of the same or related subject. In this approach, social studies teachers want to provide or instill the fundamental concepts necessary to familiarize students with topics they will revisit in greater depth as they mature. The broad-based approach to social studies represents a spiraling curriculum model. Many different topics are introduced in a given school year. In subsequent years the same topics are presented again in more depth. Thus, in-depth learning builds upon a prior knowledge base. Achieving familiarity with a wide range of topics puts the historical period or geographic place in the context of what came before and what follows. Essential vocabulary to understand the period or place is contextualized and forms the basis for conceptualization.

Understanding the essential vocabulary and key ideas is important in the textbook-based or theme-based approach for all students. For instance, if the topic is the Middle Ages, students have to understand what a castle is or what nobility means or the basic social structure of the Middle Ages. For students with mild learning problems, basic vocabulary becomes pivotal for concept development. Some children with mild learning problems will need support in identifying, reading, and understanding the fundamental vocabulary and related concepts. Vocabulary and concept development can be done several ways and should include a variety of practice opportunities.

Vocabulary. Social studies is vocabulary-intensive. One of the major causes of poor comprehension and faulty reading is the nature and type of vocabulary found in social studies content. Limits must be placed on simplifying the specialized terms or the meaning necessary for more complex understanding will be nonfunctional or misleading. Parker and Jarolimek (1997) have identified seven areas of vocabulary that must be considered in social studies instruction: technical terms (such as veto or meridian), figurative terms (such as cold war), words with multiple meanings (such as cabinet or bill), terms peculiar to a locality (such as truck or borough), words easily confused with other words (such as alien for allies), acronyms (such as NATO or NASA), and quantitative terms (such as fortnight). Words representing these categories need special attention in social studies.

In many textbook-based units, students are given a list of terms. The students research or are instructed in definitions for those terms. Written drill or practice often is given to reinforce retention. Students work with terms presented in a variety of formats (e.g., writing definitions or using the word in context). Vocabulary also can be used to describe situations or representations of content in the unit (e.g., students might be given a picture and asked to label or describe objects depicted, such as a castle, a knight, or a joust). A variety of practice activities on essentially the same material assists in comprehension and retention. These vocabulary study techniques are simple in nature and, with a minimum of guidance, can be completed successfully by children with mild learning problems.

At the end of instruction, some kind of evaluation for vocabulary comprehension is given. The object of the evaluation is twofold: (a) to determine what students have learned and (b) to provide students with positive views of themselves as learners. Students with mild learning problems can be successful with drill-and-practice activities with minimum guidance from teachers. Multiple exposure to 
vocabulary seems to be an effective way for many students with disabilities to learn. When students with mild learning problems learn these essential vocabularies, as reflected by a good score on a social studies quiz, they can experience a sense of accomplishment.

Special education teachers' tasks are to ensure that students understand and complete the drill-and-practice activities the social studies teacher provides. Modifications such as rewording directions, changing print size, or teaching students organizational skills for meeting deadlines become part of the accommodation responsibility of special education teachers. Task monitoring that accounts for teaching students how to attend and complete tasks that exceed normal classroom demands also becomes part of the responsibility of special education teachers.

Concept Formation. Students with mild learning problems, as with all students, must have acquired and retained knowledge of the basic vocabulary before they can understand higher level concepts within a unit. For example, students are likely to have great difficulty comprehending the social hierarchy of the Middle Ages without understanding the vocabulary used to describe the time period. Many students with mild learning problems have trouble deducing meaning from the context. By building on vocabulary that they know, they can incorporate new associations.

\section{A Model for Large-Group Instruction}

Organization, organization, organization. One of the often-cited weaknesses of students with mild learning problems is lack of organizational skills. Given the extensive amount of content delivered in a text-based model of social studies, students who are not organized are often at a loss for identifying key vocabulary and concepts, assignments, and due dates for projects, readings, and quizzes. In a text-driven social studies model, many students with organizational problems would benefit from a fairly standardized and predictable unit format.

Predictability. In a standardized format, activities basically are presented in a predictable order (e.g., students know for better or worse what to expect instructionally). In Mr. Maher's sixth-grade class, for example, each lesson is designed for a 2-week period. Each lesson has a vocabulary list of 20 words and four essay questions. For a history or geography unit, Mr. Maher typically gives students a blank map, which is used throughout the unit. The students are required to identify and locate 9 to 12 places related directly to the unit of study. Mr. Maher's pattern of instruction is to work with the vocabulary words for a certain number of days until all the students understand all the key words, work on map identifications, and near the end of the unit discuss and outline the answers for the essay questions.

The student's responsibility is to write out the definitions and the essay questions in sentence form and to learn the places on the map. Within the 2-week unit, students engage in at least one, but usually two or three, high-interest, lowaccountability activities (e.g., coloring a map to show a historical period or building a model in which the effort and the attempt are as important as the results). For Mr. Maher, the high-interest activities do not represent a large percentage of the grade. The focus of accountability is on the vocabulary, map identification, and essays.

At the end of each 2-week unit, Mr. Maher gives a quiz that essentially covers the vocabulary, places on the map, and concepts in the essays. Information from the essays is presented in a multiple-choice format. If the students have completed four essays, they can expect at least four of the quiz questions to be based on the essays.

Positive Self-Image. Any student who has done the essay and mapping assignments and learned the vocabulary in a 2week period can do well. The focus of the test on the vocabulary and map balances the skills of the remedial student with the interests and needs of the higher level students in the same class. Students with poor academic records know they can be successful in the class by focusing time and energy on the basics. They can do as well as the students who typically are high achievers. Students who complete basic vocabulary activities, map identification, and essays rapidly can spend more time on high-interest activities.

Task Completion. Most assignments are not collected or graded until the end of the unit. This 2-week period allows for differences in rate of task completion. Students can take from 1 to 10 days to define terms, identify locations, and complete essays. Students with problems in reading, writing, or study skills are not likely to write assigned definitions in 1 day. Students with mild disabilities often need time accommodations to complete the required assignments. One suggested accommodation is to assign less content to students with mild disabilities (Henley, Ramsey, \& Algozzine, 1996), an accommodation that is not acceptable to most social studies teachers (Passe \& Beattie, 1994). Another suggested accommodation is to lessen the amount of practice time with key concepts, an accommodation that is contrary to instructional research findings. Accommodations like Mr. Maher's may be the middle ground - and an instructionally sounder path for students with mild learning problems under a text-based social studies model.

Organizational Needs. In keeping with students' organizational needs, Mr. Maher requires that all written work be 
kept in a single folder. The purpose of the folder is to keep the students organized by requiring them to arrange all written work in a standardized format. For example, on the first day for each unit, they are given a note-taking sheet with vocabulary printed on one side and essay items on the other, which they immediately place on the first page of the folder. Words are presented in vertical lists, with spaces for writing definitions or notes for definitions. As students read texts or listen to lectures, they can take notes on this sheet.

Page 2 of the folder is reserved for the blank map to be used in the unit to label required places. As the unit progresses, the students are expected to produce the required places or formations. Following the map page are rewritten definitions that the students produce in complete sentences. Rewriting reinforces what was learned during the notetaking, and the complete sentence format is necessary so the students later can understand what they have written. Following the rewritten definitions is a page for rewritten essays; complete sentences and standard paragraph form are required for the rewritten essay notes. Following the rewritten vocabulary and essays are whatever written activities were done with the unit.

Activities. The purpose of the activities is to allow greater indepth participation in the topic for students who have acquired the basic unit content. Complementing the simple nature of the required tasks (e.g., in writing definitions, students who need more time to finish required content can do so on their own time as homework or in study hall), the activities provide these students with a change of pace from application of basic skills and even can account for differences in learning styles or talents.

In the study of the Middle Ages, for example, an activity could be one centering on how occupations formed the basis of assigning last names. Students could match the occupation to the name (e.g., "Carter" is a person who hauls things in wagons, or "Smithe" is the last name of a person who works with iron). Other examples of high-interest activities include drawings depicting the relationship between the serfs and their lords and poems describing life as a knight. Activities such as these can be used to expand the knowledge base of the unit through personally meaningful projects.

Review. Next in the folder usually would be a cloze review using all or most of the vocabulary words in a narrative context. For example:

"During the Middle Ages, the were the agricultural workers. These workers were bound to a manor, the land owned by a member of the

The students fill in the blanks, and class discussion ensues, if necessary, to clarify or expand responses. The completed responses are as follows:

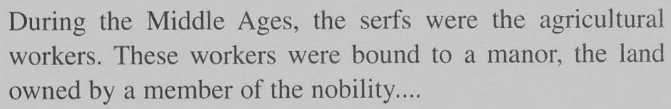

During the Middle Ages, the serfs were the agricultural workers. These workers were bound to a manor, the land owned by a member of the nobility....

Accountability. The quiz for the unit is the last entry in the folder. Using the concept of completed folders, students are accountable for all assignments, and each assignment is weighted approximately the same. As a result, students who have problems taking tests find less emphasis on testing and more focus on written work.

Mr. Maher has provided an organizational framework that accounts for individual differences and leads to conceptual block-building in social studies. The 2-week time frame provides structure and predictability. Flexibility within the structure also allows students with mild learning problems more time for instruction, practice, and assistance with the content of the unit. Students with mild learning problems can be successful in acquiring a knowledge base for future classes and develop positive self-esteem through awarded grades.

\section{Potential Problems}

The bright side of text-based group lessons was seen in the model unit on the Middle Ages. Now for a word from the dark side: At times group work breaks down because some of the children, often those with mild learning or social disabilities, do not do any of the work. Some of the children accomplish little or nothing and by default earn failing grades. As a result, these children may have learned nothing related to the social studies content. The danger in largegroup instruction is that some children's problems are so serious that teacher intervention is directed more to task completion and motivation than to instruction in social studies content. Potential problems under a large-group or whole-class text-based model of social studies seem familiar to potential problems found in a child-centered model. Is it possible that many models, or at least aspects of models, are necessary to meet students' divergent needs? By embedding aspects of models that match students' entry skills, many potential problems can be reduced or eliminated.

\section{KNOWLEDGE ACQUISITION}

\section{Prerequisite Skills}

The more a model employs a text-driven approach, the greater is the risk that "It's boring!" will become the social studies motto (at least until success can or cannot be demonstrated). The greater the emphasis on the child-centered 
approach, the greater is the possibility of developing arts and crafts skills at the expense of a sound knowledge base in social studies. Yet, a striking similarity exists between potential problems across all basic models of social studies instruction. The problematic aspects of group activities, cooperative or not, stem from the same source as situations in which children do not stay on task, do not complete assignments, refuse to hand in homework, fail quizzes, and decline to participate in group discussion. In these cases, low grades flash like a beacon, highlighting failure and promoting low self-esteem. Who's to blame for poor achievement across these very different social studies instructional models and philosophies? Elementary, my dear Watson. The invisible villain is the missing prerequisite skill.

\section{Entry Skill}

To be successful in learning social studies concepts under any model, task demands must match the students' skill levels. This is not new information. Students need not stay at a low level, but to require them to learn new concepts through activities that exceed their skill levels is to doom them and their teachers to the tragedy of Sisyphus-always condemned to reach that impossible mountaintop. Just as Sisyphus is a myth, so is success in social studies for children with mild learning problems without the appropriate instructional support.

\section{Abundance of Instructional Resources}

There is no lack of sources for instructional strategies either for identifying prerequisite skills or for locating strategies of instruction for acquisition, retention, or generalization to new content. Textbooks for teaching children with mild learning problems are easily accessible. Techniques for teaching social studies under a variety of models also are available. The classic best-seller Social Studies in Elementary Education (10th ed.) by Parker and Jarolimek (1997) is bursting with ideas, as is Middle Grades Social Studies by Allen and Stevens (1994).

Representative texts emphasizing a more child-centered approach or the "new social studies" are Children and Their World: Strategies for Teaching Social Studies (5th ed.) by Welton and Mallan (1996) and Elementary Social Studies: A Whole Language Approach by Farris and Cooper (1994). The National Council for the Social Studies (NCSS) has produced a 406-page bulletin, Handbook on Teaching Social Issues, which describes an "issues-centered" curriculum (Evans \& Saxe, 1996).

\section{Inclusion Paradigm Shift Revisited}

A diverse student population has become the norm in any social studies class. When trying to accommodate the wide range of ethnic, physical, intellectual, and social differences of students, a variety of administrative approaches has been used. Ironically, these approaches have done little to foster diversity in the classroom. Typical approaches have included grouping, special classes, and pull-out programs (Welton \& Mallan, 1996). These exclusionary techniques are being replaced by instruction or attempts at instruction in the general education setting.

\section{Limited Services}

School districts often provide full- or part-time aides to assist children with severe to moderate disabilities. Juan, for example, who has muscular dystrophy, has an aide, and Patrick, who has a hearing disability, has an interpreter. For Tim, who can't organize his thoughts, or for Daniel, who is prone to outbursts, support personnel is more limited.

Ideally, Tim and Daniel, and all other students with mild disabilities, have access to a special education teacher or a classroom teacher highly skilled in teaching techniques that accommodate their students' needs. The picture of the ideal team approach - the special education teacher and general education teacher collaborating hand in hand, side by side, day by day, sharing compatible philosophies-is more surreal than real. Anyone who buys this educational picture is ready to purchase the Brooklyn Bridge at cost.

\section{Collaboration}

Accommodating the needs of children with mild disabilities under the "romancing the team" approach simply is not feasible for all teachers or all students. One of the widely accepted practices of the 1990s was collaboration between general and special educators. Although the collaboration model has been applied successfully in some situations (Idol, Nevin, \& Paolucci-Whitcomb, 1994), the stamina of teachers in terms of time and opportunity has been strained severely. Not enough special education teachers are being educated to fill the growing demands of children with mild disabilities (McCoy, 1996).

\section{Inclusion}

Inclusion, the movement designed to bring special education services to the general classroom, changed the instruction paradigm of moving children with special needs into special settings for special instruction by special teachers. This shift also means that most children with mild learning problems will be instructed directly by the general education teacher in all areas, including social studies. The inclusion paradigm left the collaboration role of teachers "to be determined."

\section{Special Education Presence}

The problem with inclusion is one of special education presence. Special education teachers are assigned to 
students who are enrolled in a variety of classrooms. No matter how skilled special education teachers are, they physically cannot be in more than one room at a time. The solution lies in how special educators can modify the environment while reducing the time they are present physically in the classroom. With respect for the classroom social studies model, the presence and the influence of special techniques accommodating students' needs are possible at most times given proper planning and a paradigm shift in roles. Special educators will reduce their direct instructional contact with students, but services and instructional impact must equal or exceed past service models of delivery. Under the inclusion model, students with mild learning problems will need more access to carefully constructed or orchestrated instructional modifications and less time with direct instruction from teachers with special training.

Modified materials, models of expected products, and guidelines for completing tasks are only three of many techniques that can provide the special presence needed without providing the continuous presence of the special education teacher. Special education teachers may find themselves less and less involved in providing instruction directly to students and more and more involved in providing instructional materials that can be used independently.

\section{THE NEW INCLUSION MODEL}

To be in five classrooms at one time, the special education teacher of the future will have to become a specialist within the instructional design field. Fortunately, technological advances have made creation of materials and modification of materials less time-intensive. The special educator will have to design materials and environmental settings that provide access to social studies content by taking into account the instructional skills of the students and classroom demands. So far, no large-scale model of this "new inclusion" paradigm exists.

The new inclusion model has put educators at a crossroad where preparation and opportunity meet. To paraphrase John Maynard Keynes, "I do not know which makes a teacher more conservative - to know nothing but the present or nothing but the past." For certain, teachers engaging in the new inclusion paradigm will have to be far from conservative as they dare to invent models of inclusion that account for diversity in students and diversity of service delivery. As Thoreau said, "If you have built castles in the air, your work need not be lost; that is where they should be. Now put the foundations under them."

\section{REFERENCES}

Allen, M. G., \& Stevens, R. L. (1994). Middle grades social studies: Teaching and learning for active and responsible citizenship. Boston: Allyn \& Bacon.

Baker, J. M., \& Zigmond, N. (1990). Are regular education classes equipped to accommodate students with learning disabilities? Exceptional Children, 56(6), 515-526.

Bender, W. N., \& Ukeje, I. C. (1989). The other side of placement decisions: Assessment of the mainstream learning environment. Remedial \& Special Education, 9(5), 28-33.

Bracey, G. W. (1993). Elementary curriculum materials: Still a long way to go. Phi Delta Kappan, 74(8), 654, 656.

Bulgren, J., \& Lenz, K. (1996). Strategic instruction in the content areas. In D. D. Deshler, E. S. Ellis, \& B. K. Lenz (Eds.), Teaching adolescents with learning disabilities (2d ed.). Denver, CO: Love.

Bulgren, J. A., Schumaker, J. B., \& Deshler, D. D. (1994). The effects of recall enhancement routine on the test performance of secondary students with and without learning disabilities. Learning Disabilities Research \& Practice, 9(1), 1-11.

Carnine, D., Crawford, D., Harniss, M., \& Hollenbeck, K. (1995). Understanding U.S. history: Vol 1. Through the Civil War. Eugene, OR: Considerate Publishing.

Coerr, E. (1986). The Josefina Story Quilt. Illus. B. Begen. New York: Harper \& Row.

Cohen, E., \& Lotan, R. (1990). Teacher as supervisor of complex technology. Theory into Practice, 29(1), 78-84.

Cohen, E., Lotan, R., \& Catanzarite, L. (1990). Treating status problems in the cooperative classroom. In S. Sharan (Ed.), Cooperative learning: Theory and research (pp. 203-229). New York: Praeger.

Ellis, E. S. (1993). Writing strategies for thought-full classrooms. Tuscaloosa, AL: SMART Strategy Associates.

Ellis, E. S. (1994). An instructional model for integrating content-area instruction with cognitive strategy instruction. Reading \& Writing Quarterly: Overcoming Learning Difficulties, 1, 63-90.

Evans, R. W., \& Saxe, D. W. (1996). Handbook on teaching social issues (NCSS Bulletin 93). Washington, DC: NCSS.

Farris, P. J., \& Cooper, S. M. (1994). Elementary social studies: A whole language approach. Madison, WI: Brown \& Benchmark.

Fernlund, P., \& Crowell, S. (1990, November 18). Complex instruction in elementary social studies. Paper presented at meeting of National Council for the Social Studies, Anaheim, CA.

Gersten, R., Brengelman, S., \& Jimenez, R. (1994). Effective instruction for culturally and linguistically diverse students: A reconceptualization. Focus on Exceptional Children, 21(1), 1-16.

Goodlad, J. (1984). A place called school. New York: McGraw-Hill.

Henley, M., Ramsey, R., \& Algozzine, R. F. (1996). Characteristics of and strategies for teaching students with mild disabilities (2d. ed.). Boston: Allyn \& Bacon.

Horton, S. W., Lovitt, T. C., \& Slocum, T. (1988). Teaching geography to high school students with academic deficits. Learning Disability Quarterly, 11, 371-379.

Idol, L., Nevin, A., \& Paolucci-Whitcomb, P. (1994). Collaborative consultation ( $2 \mathrm{~d}$ ed.). Austin, TX: Pro-Ed. 


\section{SPECIAL EDUCATION POLICY AND PRACTICE}

\section{Accountability, Instruction, and Social Challenges}

Thomas M. Skrtic

Karen R. Harris

James G. Shriner

This is an excellent book that addresses the policy shift in special education from procedural compliance to standards-based accountability and the changing conditions of practice under reform. It covers the major problems of implementing reform and presents several practices and models to improve the conditions of special education practice.

The authors support a collaborative environment for service delivery and inclusive work atmospheres with research-based instructional practices. The book gives prevention and intervention strategies including specific reading, writing, and mathematics instructional techniques. Other topics include transition, selfdetermination, school violence, health needs, and literacy instruction for Latino students.

The focus in the last part of the book is oriented to human needs and opportunities that will shape special education practice in the future including individual and environmental conditions. These include welfare of children working across social contexts and providing a planning framework for achieving integrated services.

\section{SPECIAL FEATURES}

- Clear explanation of policy shifts from procedural compliance with federal and state law to academic performance of students with disabilities

- Recommends strategies for improving academic learning for students with disabilities

- Considers human needs and environmental conditions that contribute to educational achievement of children

- Provides an action-oriented planning framework for achieving integrated services 
James, M., \& Zarrillo, J. (1989). Teaching history with children's literature: A concept based, interdisciplinary approach. Social Studies, $80,153-158$.

Johnson, D. D., Toms-Bronowski, S., \& Pittleman, S. D. (1982). Vocabulary development. In R. E. Kretschmer (Ed.), Reading and the hearing impaired individual (monograph). Volta Review, 84, 11-24.

McCoy, K. M. (1996). Teaching special learners in the general education classroom (2d ed.). Denver, CO: Love.

Lehrman, F. (1990). Loving the earth: A sacred landscape book for children. Celestial Arts, 1, 48 pages.

Lewis, C. (1987). Long ago in Oregon. Illus. J. Fontaine. New York: Harper \& Row.

National Commission on Excellence in Education. (1983). A nation atrisk: The imperative for educational reform. Washington, DC: Author.

National Council for the Social Studies Task Force (NCSS). (1994). Expectations of excellence: Curriculum standards for social studies. Washington, DC: Author.

National Council for the Social Studies Task Force on Early Childhood Elementary Education. (1990). Social studies curriculum planning resources. Washington, DC: NCSS.

Parker, W. C., and Jarolimek, J. (1997). Social studies in elementary education. Columbus, OH: Merrill.

Passe, J., \& Beattie, J. (1994). Social studies instruction for students with mild disabilities: A progress report. Remedial \& Special Education, 4(15), 227-233.
Routman, R. (1991). Invitations: Changing as teachers and learning K-12. Portsmouth, NH: Heinemann.

Routman, R. (1994). Invitations: Changing as teachers and learners K-12. In P. J. Farris \& S. M. Cooper (Eds.), Elementary social studies: A whole language approach. Madison, WI: Brown \& Benchmark.

Saxe, D. W. (1994). Social studies for the elementary teacher. Needham Heights, MA: Allyn \& Bacon.

Schumm, J. S., \& Vaughn, S. (1991). Making adaptations for mainstreamed students: General classroom teachers' perspectives. Remedial \& Special Education, 12(4), 18-27.

Smith, J. A., Monson, J. A., \& Dobson, D. (1992). A case study on integrating history and reading instruction through literature. Social Education, 56(7), 370-375.

Turner, T. N. (1976). Making the social studies textbook a more effective tool for less able readers. Social Education, 40, 38-41.

Welton, D. A., \& Mallan, J. T. (1996). Children and their world: Strategies for teaching social studies (5th ed.). Geneva, IL: Houghton Mifflin.

Whinnery, K. W., Fuchs, L. S., \& Fuchs, D. (1991). General, special, and remedial teachers' acceptance of behavioral and instructional strategies for mainstreamed students with mild handicaps. Remedial \& Special Education, 12(4), 6-17.

Ysseldyke, J., \& Algozzine, B. (1990). Introduction to special education. Boston: Houghton Mifflin.

\section{PERMISSIONS AND COPYRIGHT}

All rights are reserved. No part of this publication may be reproduced, photocopied, faxed, stored in a retrieval system, or transmitted in any form or by any means, electronic, mechanical, recording or otherwise, without the prior written permission of the publisher.
Back issues are available for sale. Reproduction requires permission and payment of fees. It is illegal and a violation of federal copyright law to reproduce this publication without permission. Direct all inquiries to the permissions editor. 